\title{
CERAI TALAK DI KOTA PALOPO (FAKTOR PENYEBAB DAN SOLUSINYA DALAM STUDI KASUS DI PENGADILAN AGAMA)
}

\author{
Muhammad Tahmid Nur \\ IAIN Palopo \\ Jl. Agatis, Kel. Balandai, Kota Palopo, Sulawesi Selatan, Indonesia \\ E-mail: tahmid nur@iainpalopo.ac.id
}

\begin{abstract}
Marriage is one of the manifestations of human nature in the world to find happines, and make their descendant. Unfortunately, not all marriages are lasting until the end of the age, and not a litle ended in divorce. one case of divorce, is when a husband on his wife filed for divorce in religious courts. It dilator overshadow the many factors causing the disharmony that leads to divorce. However, the judiciary and the associated constantly seek and forge solutions to minimize the number of divorce cases divorce tends to increase from year to year.
\end{abstract}

Keywords: Divorece, Cause of Divorce, Court of Religious

\begin{abstract}
Abstrak
Pernikahan adalah salah satu perwujudan fitrah manusia di dunia untuk mendapatkan kebahagiaan bersama pasangan, dan membina keturunannya. Sayangnya, tidak semua pernikahan tersebut langgeng hingga akhir usia, tetapi tidak sedikit yang berakhir pada perceraian. Salah satu kasus perceraian, adalah ketika seorang suami mengajukan permohonan talak atas istrinya di pengadilan agama. Hal tersebut dilator belakangi dengan berbagai faktor penyebab ketidakharmonisan yang berujung pada perceraian. Meskipun demikian, pihak pengadilan dan yang terkait senantiasa mencari dan menempu solusi untuk meminimalisir jumlah kasus cerai talak yang cenderung meningkat dari tahun ke tahun.
\end{abstract}

Kata Kunci: Cerai Talak, Faktor Penyebab Cerai Talak, Pengadilan Agama

\section{PENDAHULUAN}

Salah satu bentuk dari pelaksanaan fitrah manusia dan telah menjadi hukum alam yaitu melakukan pernikahan atau perkawinan dengan pasangannya. Allah telah menciptakan makhluk di alam semesta ini secara berpasang-pasangan. Ibarat siang dan malam, diciptakan laki-laki menjadi pasangan bagi wanita yang sama-sama dari makhluk manusia, dan pada hewan dipasangkan antara jantan dengan betina. Pada hakikatnya pernikahan atau perkawinan telah diatur menurut syariat Islam untuk membedakan pergaulan hidup manusia dengan jenis makhluk selainnya, misalnya binatang. Pasangan laki-laki dan perempuan bertemu dalam 
pandangan pertama, mencari kesesuaian, yang kemudian diiringi perasaan saling membutuhkan. ${ }^{1}$

Pernikahan merupakan sunnahtullah yang berlaku pada setiap makhluk hidup; baik pada manusia, hewan, maupun tumbuh-tumbuhan. Ia adalah suatu cara yang dipilih oleh Allah swt. sebagai jalan bagi makhluknya untuk berkembang biak dan melestarikan hidupnya. Pernikahan akan berperan setelah masing-masing pasangan siap melakukan peran yang positif dalam mewujudkan tujuan pernikahannya. ${ }^{2}$

Langgengnya kehidupan dalam ikatan perkawinan merupakan suatu tujuan yang sangat diutamakan dalam Islam. Akad nikah diadakan untuk selamanya agar suami isteri bersama-sama dapat mewujudkan rumah tangga sebagai tempat berlindung, mencurahkan kasih sayang dan memelihara anak-anaknya sehingga mereka tumbuh dengan baik. Ikatan pernikahan di antara suami isteri adalah ikatan yang paling suci dan kokoh. Tidak ada suatu dalil yang lebih jelas menunjukkan kecuali tentang kesucian ikatan rumah tangga yang begitu agung, sehingga Allah menamakan ikatan perjanjian antara suami isteri tersebut dengan istilah misaqan galidzan "perjanjian yang kokoh", ${ }^{3}$ Sebagaimana disebutkan oleh Allah swt. dalam firmannya dalam QS. An-Nisa/ 4: $21^{4}$.

Dan mereka (isteri-isterimu) telah mengambil dari kamu Perjanjian yang kokoh.

Begitu kuat atau kokohnya hubungan antara suami isteri, sehingga tidak sepantasnya hubungan tersebut dirusak dan dilepaskan begitu saja. Setiap usaha yang menyepelehkan hubungan pernikahan dan melemahkannya sangat dibenci oleh Islam, karena hal itu merusak kebaikan dan menghilangkan kemaslahatan.

Meskipun demikian, kehidupan dalam membina rumah tangga tidak selalu berjalan harmonis. Kadang kala muncul permasalahan yang kemudian menjadi besar yang mungkin dibesar-besarkan oleh salah satu pihak, sehingga rumah tangga harmonis yang didambakan oleh pasangan suami isteri tersebut tidak tercapai dan berakhir dengan perceraian. Padahal, perceraian merupakan perbuatan yang dibenci oleh Allah. ${ }^{5}$

Siapa pun orang yang merusak hubungan dan mencetuskan perceraian di antara suami isteri, tidak akan mendapatkan tempat terhormat dalam Islam. Meskipun demikian, talak tetap diperbolehkan oleh Allah swt. menjadi

${ }^{1}$ Ramlan Mardjoned, Keluarga Sakinah (rumahku Syurgaku), 1 ed. (Jakarta: Media Dakwah, 1999), 51.

${ }^{2}$ Slamet Abidin dan Aminuddin, Fiqhi Munakahat I, 1 ed. (Bandung: Pustaka Setia, 1999), 9.

${ }^{3}$ Ibid.

${ }^{4}$ Departemen Agama RI, Al-Quran dan Terjemahnya Al-Jumanatul 'Ali (Bandung: CV Penerbit J-Art, 2005).

${ }^{5}$ Umi Kalsum, Risalah Fiqih Wanita, 1 ed. (Surabaya: Cahaya Mulya, 2007), 298. 
jalan terakhir, jika hubungan pernikahan di antara suami dengan istrinya tidak dapat lagi dipertahankan.

Fenomena cerai talak dalam masyarakat Islam khususnya di Kota Palopo cenderung meningkat dari tahun ke tahun, yaitu mencapai 150 kasus permohonan cerai talak pada tahun 2014 yang masuk ke Pengadilan Agama Kota Palopo, di luar perkara perceraian lainnya, sedang tahun sebelumnya (2013) terdapat 140 kasus permohonan cerai talak. Fenomena tersebut merupakan hal yang menarik untuk dikaji, sehingga artikel penelitian ini mencoba membahas tentang bagaimana terjadinya cerai talak di Kota Palopo, faktor penyebab, serta solusinya.

\section{KASUS CERAI TALAK DI PENGADILAN AGAMA KOTA PALOPO}

Setiap muslim menginginkan rumah tangganya yang sakinah, mawaddah dan warahmah, sehingga untuk mencapai rumah tangga yang baik, berbagai cara dilakukan dari kedua belah pihak baik suami maupun isteri untuk mendapatkannya. Namun semua tidak semua yang diimpikan oleh setiap pasangan suami istri terwujud, justru yang sering terjadi pada masyarakat, ikatan pernikahan yang suci tersebut kandas di tengah jalan dan berakhir di Pengadilan Agama melalui pengajuan/ permohonan perceraian. .

Apabila dalam suatu rumah tangga tujuan perkawinan diduga kuat tidak akan tercapai disebabkan oleh suatu sikap negatif dari suami atau istri yang membahayakan rumah tangganya, isteri atau suami berhak menuntut/ memohon perceraian/ talak kepada pengadilan agama setempat. perceraian seharusnya menjadi jalan terakhir yang ditempuh oleh pasangan suami istri, ketika tidak ada lagi jalan keluar lain untuk menyelamatkan keduanya.

Cerai Talak dari tahun ke tahun semakin marak terjadi karena beberapa faktor penyebab sehingga terjadi perceraian begitu pula di kota Palapo. Cerai Talak di kota Palopo terus mengalami kenaikan. Dalam kurun waktu tahun 2011-2015, terjadi kenaikan angka perkara perceraian dengan permohonan suami untuk menalak istrinya. Hal ini juga sesuai dengan pemaparan ketua pengadilan kota Palopo yaitu:

"Sejak saya menjabat, gugatan perceraian termasuk Cerai Talak itu mengalami peningkatan khususnya pada saat saya bertugas di pengadilan Agama kota Palopo, saya mulai bertugas 4 Februari 2014 dan kemudian saya di lantik 29 Januari 2014, jadi intinya adalah mengalami peningkatan." ${ }^{\prime 6}$

Demikian halnya keterangan salah satu hakim Pengadilan Agama Kota Palopo, Hj. St. Husnaena. Menurutnya bahwa kasus cerai talak pada tahun ini (2015), bahkan secara umum, kasus cerai talak terus meningkat dari tahun

\footnotetext{
${ }^{6}$ Rahmani; Ketua Pengadilan Agama Palopo, Wawancara, 23 Mei 2015.
} 
ke tahun. ${ }^{7}$ keterangan tersebut juga "diaminkan" dalam wawancara dengan panitera muda hukum yang menguatkan data sebelumnya. ${ }^{8}$

Penelitian ini juga menemukan semua perkara perceraian yang masuk ke Pengadilan Agama Kota Palopo mengalami peningkatan, bukan hanya pada perkara cerai talak saja tetapi dalam perkara cerai gugat juga mengalami peningkatan. bahkan perkara cerai gugat (istri menggugat) yang masuk jumlahnya jauh lebih banyak, misalnya tahun 2014, perkara cerai talak berjumlah 150 kasus yang diterima pihak pengadilan, sedang perkara cerai gugat mencapai 191 kasus. Secara rinci, perkara cerai talak yang terjadi di kota Palopo pada tahun 2013 dapat dilihat pada Tabel 1 berikut:

Tabel 1. Cerai Talak Tahun 2013

\begin{tabular}{|c|c|c|c|c|c|}
\hline Dikabulkan & Dicabut & Digugurkan & $\begin{array}{c}\text { Dicoret } \\
\text { dari } \\
\text { Register }\end{array}$ & Ditolak & Jumlah \\
\hline 121 & 5 & 6 & 2 & 6 & $\begin{array}{c}140 \\
\text { Perkara }\end{array}$ \\
\hline
\end{tabular}

Sumber Data: Hasil Dokumentasi di PA kota Palopo, 20 Mei 2015.

Berdasarkan tabel di atas, maka dapat dilihat perkara yang digugurkan ada 6 perkara, dicabut 5 perkara, di coret dari register 2 perkara, tidak diterima 5 perkara, ditolak 6 perkara, dan di kabulkan 121 perkara, dari jumlah keseluruhan perkara yang masuk di Pengadilan Agama kota Palopo dapat di katakan bahwa perkara Cerai Talak yang masuk di Pengadilan Agama kota Palopo pada tahun 2013 berjumlah 140 perkara.

Adapun perkara Cerai Talak di kota Palopo pada tahun 2014 dapat dilihat pada Tabel 2 berikut:

Tabel 2 Cerai Talak Tahun 2014

\begin{tabular}{|c|c|c|c|c|c|}
\hline Dikabulkan & Dicabut & Digugurkan & $\begin{array}{c}\text { Dicoret } \\
\text { dari } \\
\text { Register }\end{array}$ & Ditolak & Jumlah \\
\hline 132 & 10 & 5 & 2 & 1 & $\begin{array}{c}150 \\
\text { Perkara }\end{array}$ \\
\hline
\end{tabular}

Sumber Data: Hasil Dokumentasi di PA kota Palopo, 20 Mei 2015.

Tabel 2 menggambarkan secara akumulasi bahwa jumlah Cerai Talak tahun 2014 di pengadilan agama kota Palopo dikabulkan berjumlah 132 perkara, Sedangakan perkara yang dicabut berjumlah 10 perkara, Kemudian

\footnotetext{
${ }^{7}$ Husnaena; Hakim Pengadilan Agama Palopo, Wawancara, 3 Juni 2015.

${ }^{8}$ Mariani; Panitera Muda Hukum Pengadilan Agama Palopo, Wawancara, 24 Mei 2015.
} 
jumlah perkara yang digugurkan berjumlah 5 perkara, perkara yang dicoret dari register adalah berjumlah 2 perkara. Sedangkan, Cerai Talak yang tidak dikabulkan atau ditolak adalah berjumlah 1 perkara sehingga jumlah kasus cerai talak yang masuk ke Pengadilan Agama Palopo pada tahun 2014 meningkat menjadi 150 kasus.

Adapun yang dimaksud dengan "perkara yang dicabut" disini adalah perkara yang batalkan oleh pihak pemohon atau pihak yang berperkara di pengadilan agama. Maksud "perkara yang digugurkan" adalah perkara yang sudah masuk ke dalam pengadilan agama namun pihak yang berperkara tidak lagi datang untuk memenuhi panggilan persidangan selanjutnya. adapun "perkara yang dicoret dari register" adalah perkara yang sudah masuk ke dalam pengadilan agama namun pihak yang berperkara tidak bisa melanjutkan lagi, misalnya dikarena pihak berperkara tidak sanggup membayar uang perkara, atau karena perkara yang diajukan pihak pemohon tidak mempunyai cukup bukti.

Pada tahun 2013- 2014 Cerai Talak mengalami peningkatan dengan selisih 10 perkara. Hal ini peneliti akan gambarkan dalam bentuk diagram di bawah ini:

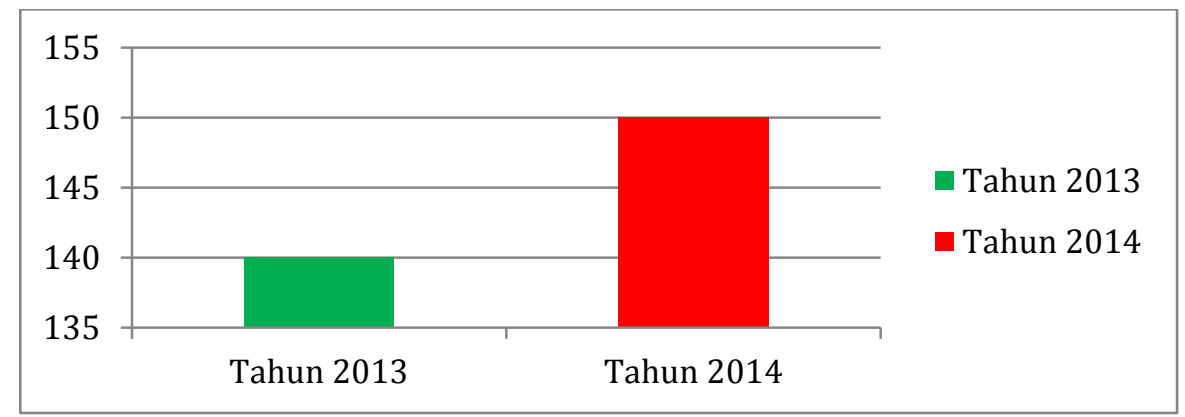

Gambar 1. Jumlah Cerai - Talak Tahun 2013 - 2014. (Sumber: Hasil

Dokumentasi di PA kota Palopo, 15 Oktober 2015)

Kemudian Cerai Talak yang masuk di pengadilan Agama kota Palopo dari bulan Januari hingga data terakhir yang dikumpulkan oleh peneliti pada tanggal 15 Oktober 2015 sebanyak 137 perkara dengan rata-rata 10 hingga 12 kasus cerai talak setiap bulannya didaftarkan pada Pengadilan Agama Kota Palopo.

Dengan beberapa data tersebut dipahami bahwa kasus cerai talak di Kota Palopo mengalami peningkatan dari tahun ke tahun, berdasarkan data perkara yang masuk ke Pengadilan Agama. Perkara cerai talak tersebut secara kesuluruhan penulis dirangkum sebagai berikut:

1. Tahun 2011: 109 kasus dari 312 kasus perceraian

2. Tahun 2012: 117 kasus dari 363 kasus perceraian

3. Tahun 2013: 140 Kasus dari 395 kasus perceraian 
4. Tahun 2014: 150 Kasus dari 511 kasus perceraian

5. Tahun 2015 ( hingga15 Oktober 2015): 137 Kasus, dengan jumlah ratarata kasus Cerai talak antara 12-13 kasus/ bulan. ${ }^{9}$

Data tersebut menggambarkan peningkatan jumlah perkara cerai talak secara signifikan, sehingga patut mendapat perhatian semua pihak.

\section{PROSEDUR CERAI TALAK DI PENGADILAN AGAMA KOTA PALOPO}

Prosedur dan proses penyelesaian perkara cerai talak di Pengadilan Agama Kota Palopo menggunakan prosedur standar yang diatur dalam Undang-undang tentang pengadilan agama, dan secara operasionalnya sebagai berikut:

1. Pemohon mendaftarkan permohonan Cerai Talak ke pengadilan agama setempat.

2. Pemohon dan Termohon dipanggil oleh pihak pengadilan agama untuk menghadiri persidangan.

3. Tahapan persidangan :

a) Pada pemeriksaan sidang pertama, hakim berusaha mendamaikan kedua belah pihak, dan suami istri harus datang secara pribadi (Pasal 82 UU No. 3 Tahun 1989);

b) Apabila tidak berhasil, maka hakim mewajibkan kepada kedua belah pihak agar lebih dahulu menempuh mediasi (Pasal 3 ayat (1) PERMA No. 2 Tahun 2003);

c) Apabila mediasi tidak berhasil, maka pemeriksaan perkara dilanjutkan dengan membacakan surat permohonan, jawaban, jawab menjawab, pembuktian dan kesimpulan. Dalam tahap jawab menjawab (sebelum pembuktian) Termohon dapat mengajukan gugatan rekonvensi (gugat balik) (Pasal 132 a HIR, 158 R.Bg). ${ }^{10}$

Apabila permohonan dikabulkan dan putusan telah memperoleh kekuatan hukum tetap, maka :

1. Pengadilan Agama/ Mahkamah syar'iah menentukan hari sidang penyaksian ikrar talak

2. Pengadilan agama/mahkamah syar'iah memanggil Pemohon dan Termohon untuk melaksanakan ikrar talak;

3. Jika dalam tenggang waktu 6 (enam) bulan sejak ditetapkan sidang penyaksian ikrar talak, suami atau kuasanya tidak melaksanakan ikrar talak di depan sidang, maka gugurlah kekuatan hukum penetapan tersebut

${ }^{9}$ Data merupakan hasil rangkuman dari keseluruhan pengajuan perkara cerai talak yang diperoleh dari Dokumentasi Pengadilan Agama Palopo hingga tanggal 15 Oktober 2015.

${ }^{10}$ Rahmani; Ketua Pengadilan Agama Palopo, Wawancara. 
dan perceraian tidak dapat diajukan lagi berdasarkan alas an hukum yang sama (Pasal 70 ayat (6) UU No. 7 Tahun 1989).

4. Setelah ikrar talak diucapkan panitera berkewajiban memberikan Akta Cerai sebagai surat bukti kepada kedua belah pihak selambat-lambatnya 7 (tujuh) hari setelah penetapan ikrar talak (Pasal 84 ayat (4) UU No. 7 Tahun 1989). ${ }^{11}$

Prosedur perkara Cerai Talak di pengadilan Agama kota Palopo tersebut merupakan prosedur penyelesaian perkara cerai talak standar pengadilan agama lainnya di seluruh Indonesia, dan hal ini tidak jauh berbeda dengan prosedur proses penyelesaian perkara cerai gugat yang diajukan oleh pihak istri.

\section{FAKTOR PENYEBAB CERAI TALAK DI KOTA PALOPO}

Secara umum, pengajuan perkara perceraian di Pengadilan Agama Kota Palopo (baik perkara cerai Talak maupun perkara cerai gugat) dalam kurun waktu tahun 2011 hingga Oktober 2015 di sebabkan berbagai macam faktor, antara lain karena faktor: krisis akhlak, cemburu, cacat biologis, faktor ekonomi, tidak ada tanggung jawab, gangguan pihak ketiga, dan tidak ada keharmonisan dalam rumah tangga. ${ }^{12}$

Dari data yang diperoleh, berbagai faktor penyebab perceraian (cerai talak maupun cerai gugat) dalam 1465 perkara perceraian yang diajukan ke Pengadilan Agama Palopo dari tahun 2011 sampai dengan (15 Oktober) 2015, distribusinya adalah: krisis akhlak $0.55 \%$, ekonomi 0,89\%, cemburu $1,50 \%$, tidak ada tanggung jawab 16,31 \%, gangguan pihak ketiga 9,76 \%, tidak ada keharmonisan 59,80 \%, dan lain-lain 11,19\%.

Faktor penyebab perceraian yang diajukan dalam perkara perceraian di Pengadilan Agama Palopo didominasi oleh faktor ketidakharmonisan (59,80\% atau 876 perkara) dan karena tidak adanya tanggung jawab (16.31\% atau 239 perkara). Meskipun demikian di antara faktor tersebut seringkali dipengaruhi oleh faktor-faktor selainnya, misalnya faktor ketidakharmonisan dapat dipengaruhi oleh faktor ekonomi, kecemburuan, gangguan pihak ketiga, dan lainnya.

Berikut beberapa faktor yang menurut responden berperan dalam memicu timbulnya permasalahan dan konflik dalam sebuah rumah tangga, sehingga pada akhirnya pihak suami memilih jalan untuk mengajukan cerai talak kepada pengadilan agama:

1. Tidak Direstui Orang Tua.

\footnotetext{
${ }^{11}$ Ibid.

${ }^{12}$ Data dari Dokumentasi Pengadilan Agama Kota Palopo pada bulan Mei 2015
} 


\section{0 | Muhammad Tahmid Nur}

Pernikahan yang dilaksanakan oleh kedua mempelai senantiasa mengharapkan restu dari kedua orang tua sebagai salah satu faktor pendukung dalam membina rumah tangga yang baik. Tidak adanya restu dari orang tua, apalagi tidak ada dukungan dari keduanya dapat menjadi ujian berat dalam sebuah rumah tangga

Menurut Mustika binti Anwar salah satu responden yang berperkara menerangkan bahwa penyebab Cerai Talak yang diajukan oleh suaminya adalah berawal dari tidak adanya restu dan dukungan dari kedua orang tua yang membuat rumah tangganya menjadi tidak harmonis, sehingga suaminya mengambil jalan Cerai Talak. Hal tersebut melahirkan ketidakharmonisan dengan lahirnya perselisihan setiap saat, dan kemudian menjadi penyebab masuknya pihak ketiga ke dalam rumah tangga keduanya. ${ }^{13}$

2. Tidak ada Tanggung Jawab

Tanggung jawab merupakan kesadaran manusia akan tingkah laku atau perbuatannya, baik yang disengaja maupun tidak disengaja. Tanggung jawab juga berarti berbuat sebagai perwujudan kesadaran akan kewajiban.

Tanggung jawab bersifat kodratikarena telah menjadi bagian dari kehidupan manusia, bahwa setiap manusia pasti akan memikul suatu tanggung jawab sesuai dengan kedudukan dan perbuatannya. Apabila seseorang tidak mau memiul tanggung jawabnya, maka akan ada pihak lain yang dirugikan dan dapat memaksa untuk tindakan tanggung jawab tersebut. apalagi dalam sebuah rumah tangga, tanggung jawab merupakan sebuah kewajiban yang seharusnya dilaksanakan dalam membinanya.

Ketua Pengadilan Agama Palopo berpendapat:

"Kalau saya lihat tidak jauh beda penyebab perkara cerai talak dengan cerai gugat yaitu seputar masalah ekonomi, perselingkuhan, tanggung jawab yang tidak dipenuhi isteri, dan juga isteri kurang perhatian terhadap keluarga suami"14

Pendapat Ketua Pengadilan Agama Palopo juga ditegaskan oleh St. Husnaena salah satu hakim pengadilan agama yang menyatakan bahwa faktor penyebab Cerai Talak adalah adanya kekerasan dalam rumah tangga antara pihak suami dan isteri, dan kurangnya bertanggung jawab suami atau istri terhadap keluarga. ${ }^{15}$

3. Krisis akhlak

Krisis akhlak terjadi karena longgarnya pegangan terhadap Agama yang menyebabkan hilangnya pengontrol dari dalam diri manusia. Apabila hukum dan norma-norma dalam masyarakat juga lemah, maka hilanglah seluruh alat kontrol pada anggota masyarakat. Akibatnya, manusia dapat berbuat sesuka

13 Mustika bte Anwar; Pihak Berperkara di Pengadilan Agama Kota Palopo, Wawancara, 17 Maret 2015.

${ }^{14}$ Rahmani; Ketua Pengadilan Agama Palopo, Wawancara.

${ }^{15}$ Husnaena; Hakim Pengadilan Agama Palopo, Wawancara. 
hati dalam melakukan pelanggaran tanpa ada perasaan bersalah. Tentang krisis akhlak tersebut juga dikemukakan Abdul Rivai, salah seorang Hakim Pengadilan Agama Kota Palopo dalam wawancara:

"Krisis akhlak merupakan salah satu faktor perceraian itu terjadi karena suami kurang pendidikan dan jauh dari perintah Allah swt. Kemudian anak, kurangnya pembinaan moral yang dilakukan oleh orang tua, sekolah dan masyarakat sudah kurang efektif. Selanjutnya penanggung jawab pelaksanaan pendidikan di negara kita adalah Keluarga, Masyarakat dan Pemerintah. Ketiga institusi pendidikan sudah terbawa oleh arus kehidupan yang mengutamakan materi tanpa diimbangi dengan pembinaan mental spiritual". ${ }^{16}$

Krisis akhlak terjadi karena derasnya arus budaya hidup materialistik, hedonistik dan sekularistik. Derasnya arus budaya yang demikian didukung oleh para "penentu pembangunan" yang semata-mata mengeruk keuntungan material dengan memanfaatkan para remaja tanpa memperhatikan dampaknya bagi kerusakan akhlak para generasi penerus bangsa. hal tersebut juga tidak didukung oleh kesadara setiap keluarga, lingkungan, dan lembaga pendidikan yang ada akan pentingnya akhlakul karimah dan moralitas kebangsaan yang tinggi bagi generasi penerus bangsa ini.

4. Tidak ada Keharmonisan

Keharmonisan keluarga adalah situasi dan kondisi dalam keluarga di mana di dalamnya tercipta kehidupan beragama yang kuat, suasana yang hangat, saling menghargai, saling pengertian, saling terbuka, saling menjaga dan diwarnai kasih sayang dan rasa saling percaya sehingga memungkinkan anak untuk tumbuh dan berkembang secara seimbang. Apabila dalam suatu hubungan kekeluargaan tidak tercipta dan terbentuk keharmonisan dapat mempengaruhi keutuhan rumah tangga tersebut.

Selanjutnya, menurut panitera muda pengadilan agama kota Palopo faktor penyebab Cerai Talak yaitu:

"Ada beberapa macam faktor penyebab perceraian yang kemudian memicu ketidakharmonisan di antara suami istri, sehingga berselisih terus-menerus. Yang di maksud perselisihan secara terus-menerus itu misalnya persoalan kecil dibesar-besarkan atau persoalan masa lalu diungkit-ungkit, sehingga pada akhirnya terjadi pertengkaran secara terus-menerus, mengundang hadirnya orang ketiga, juga manimbulkan rasa cemburu. faktor-faktor tersebut pada akhirnya menimbulkan perselisihan secara terus menerus ${ }^{\prime 17}$

Faktor ketidakharmonisan menjadi faktor utama dan dominan dalam pengajuan perkara cerai talak dan perkara perceraian secara keseluruhan. dengan tidak adanya keharmonisan, suami istri tidak akan merasakan tujuan

\footnotetext{
${ }^{16}$ Abdul Rivai Rinom; Hakim Pengadilan Agama Kota Palopo, Wawancara, 3 Maret 2015.

${ }^{17}$ Mariani; Panitera Muda Hukum Pengadilan Agama Palopo, Wawancara.
} 
rumah tangga yang sesungguhnya. Ketidakharmonisan akan menghilangkan rasa cinta kasih di antara keduanya, sehingga pihak suami atau istri yang tidak dapat mengatasinya, pada akhirnya akan memutuskan untuk mengakhiri rumah tangga mereka.

5. Gangguan Pihak Ketiga

Gangguan adalah suatu bentuk tindakan (perbuatan atau ucapan) yang mempengaruhi ketidakstabilan suatu keaadan yang telah ada. Gangguan dapat terjadi akibat bermacam-macam pengaruh dari dalam maupun dari luar. Gangguan pihak ketiga dapat terjadi apabila dalam suatu keluarga, ada pihak lain yang bukan merupakan anggota keluarga inti tersebut ikut masuk dalam persoalan yang terdapat di dalamnya, dan berpotensi memberi pengaruh negatif terhadap keutuhan rumah tangga. Pada umumnya, pihak ketiga ini banyak memberikan pengaruh yang dapat menyebabkan terjadinya keretakan suatu rumah tangga. Keretakan rumah tangga ini dipicu oleh hubungan yang tidak harmonis, komunikasi yang kurang, dan juga tingkat kepercayaan terhadap pasangan.

Maswarni Bugis, salah seorang panitera pengganti di antara menjelaskan hal ini dalam wawancara dengan peneliti:

"faktor-faktor yang dapat mengundang pihak ketiga masuk dan mencampuri urusan rumah tangga seseorang yaitu disebabkan faktor ekonomi, isteri tidak memperhatikan suaminya, kemudian tempat tinggal yang tidak terurus, dan isteri keluar rumah tanpa sepengetahuan suami."

Berdasarkan data tersebut di atas, maka dapat dianalisis bahwa faktor perceraian yang terjadi di kota palopo yaitu tidak di restui orang tua, tidak bertanggung jawab, krisis akhlak, cemburu, tempat tinggal, gangguan pihak ketiga, dan tidak ada keharmonisan merupakan faktor penyebab utama terjadinya perceraian di kota Palopo

Cerai Talak di Pengadilan Agama kota Palopo dari kurun waktu tahun 2011 sampai 2015 mengalami peningkatan yang dipicu oleh faktor-faktor yang menyebabkan permohonan Cerai Talak, di antaranya karena adanya gangguan pihak ketiga, ekonomi, perselingkuhan, tanggung jawab yang tidak dipenuhi isteri, dan juga isteri kurang perhatian terhadap keluarga suaminya, perselisihan secara terus menerus, isteri tidak memperhatikan suaminya, tempat tinggal yang tidak terurus, dan isteri keluar rumah tanpa sepengetahuan suami, diperparah dengan tidak adanya restu dan dukungan dari kedua orang tua dan lingkungan setempat. 


\section{SOLUSI KASUS CERAI TALAK DI PENGADILAN AGAMA KOTA PALOPO}

Seharusnya setiap anggota masyarakat, khususnya pihak yang berwenang berusaha keras untuk "mendamaikan" atau mencari solusi atau cara untuk menghindari atau bahkan memanimalisir Cerai Talak tersebut. Ketua Pengadilan Agama kota Palopo berharap agar kiranya perkara Cerai Talak berkurang bahkan kalau perlu ditiadakan dari tengah-tengah masyarakat. Bahkan ketika menghadapi perkara cerai takal yang diajukan ke lembaganya tersebut, selalu mengingatkan kepada pihak suami yang bermohon menceraikan istrinya untuk mempertimbangkan lebih mendalam, karena seorang laki-laki yang mau kawin memerlukan biaya yang cukup, agar pihak yang berperkara khususnya Cerai Talak tidak melajutkan lagi. Bahwa Seorang suami tidak boleh telalu cepat memvonis pasangannya bahwa isterinyalah yang terjelek karena semua wanita memiliki kekurangan, dan hal itu senantiasa menjadi nasehat untuk mengurungkan niatnya. Meskipun telah diberi nasehat, tetapi kebanyakan masih tetap ingin melanjutkannya. hal tersebut senantiasa dilakukan oleh pihak pengadilan dalam upaya untuk mengurangi perkara-perkara yang masuk khususnya Cerai Talak ${ }^{18}$

Sejak dari awal terbentuknya pengadilan agama di Palopo, penanganan kasus perceraian senantiasa mendominasi perkara yang masuk setiap tahunnya apabila dibandingkan dengan kasus-kasus selainnya. Dalam memanimalisir kasus cerai khususnya Cerai Talak, berbagai macam upaya yang dilakukan oleh pihak Pengadilan Agama Palopo, khususnya dalam upaya memediasi pihak yang berperkara. bahkan telah diupayakan semaksimal mungkin agar proses mediasi tersebut berjalan efektif.

Demi kenyamanan para pihak dalam menempuh proses mediasi, maka pihak yang berperkara dilibatkan secara langsung dalam proses tersebut, termasuk dalam memilih mediator yang akan membantu menyelesaikan sengketa. upaya tersebut antara lain:

1. Untuk memudahkan para pihak memilih mediator, Ketua Pengadilan menyediakan daftar mediator yang sekurang-kurangnya memuat 5 (lima) nama dan disertai dengan latar belakang pendidikan atau pengalaman dari para mediator.

2. Ketua Pengadilan menempatkan nama-nama hakim yang telah memiliki sertifikat dalam daftar mediator.

3. Jika dalam wilayah pengadilan yang bersangkutan tidak ada hakim dan bukan hakim yang bersertifikat, semua hakim pada pengadilan yang bersangkutan dapat ditempatkan dalam daftar mediator.

\footnotetext{
${ }^{18}$ Rahmani; Ketua Pengadilan Agama Palopo, Wawancara.
} 
4. Kalangan bukan hakim yang bersertifikat dapat mengajukan permohonan kepada ketua pengadilan agar namanya ditempatkan dalam daftar mediator pada pengadilan yang bersangkutan

5. Setelah memeriksa dan memastikan keabsahan sertifikat, Ketua Pengadilan menempatkan nama pemohon dalam daftar mediator.

6. Ketua Pengadilan setiap tahun mengevaluasi dan memperbarui daftar mediator. ${ }^{19}$

Mediasi adalah proses penyelesaian sengketa melalui proses perundingan atau mufakat para pihak dengan dibantu oleh mediator yang tidak memiliki kewenangan memutus atau memaksakan sebuah penyelesaian. Ciri utama proses mediasi adalah perundingan yang esensinya sama dengan proses musyawarah atau konsensus. Sesuai dengan hakikat sebuah perundingan, musyawarah atau konsensus, maka tidak diperkenankan adanya paksaan untuk menerima atau menolak sesuatu gagasan dan penyelesaian selama proses mediasi berlangsung. Segala sesuatunya harus memperoleh persetujuan dari para pihak.

Adapun prosedur mediasi yang diterapkan pada Pengadilan Agama Palopo, adalah sebagai berikut:

1. Setelah perkara dinomori, dan telah ditunjuk majelis hakim oleh ketua, kemudian majelis hakim membuat penetapan mediator untuk melaksanakan proses mediasi.

2. Setelah pihak-pihak hadir, majelis menyerahkan penetapan mediasi kepada mediator berikut pihak-pihak yang berperkara yang ditanganinya.

3. Selanjutnya mediator menyarankan kepada pihak-pihak yang berperkara supaya perkara ini diakhiri dengan jalan damai dengan berusaha mengurangi kerugian masing-masing pihak yang berperkara.

4. Mediator bertugas selama 21 hari kalender. Berhasilnya perdamaian atau tidak, pada hari ke 22, mediator harus menyerahkan kembali kepada majelis hakim hasil mediasi untuk memberikan penetapan. ${ }^{20}$

Beberapa hal yang dibahas dalam mediasi bertujuan untuk mendamaikan para pihak yang berperkara, di antaranya berbagai pertimbangan berdasarkan dalil naqli dan akli, misalnya menyadarkan para pihak bahwa perceraian yang dilakukan adalah perbuatan halal namun dibenci Allah swt. Peristiwa perceraian selain mempunyai tujuan positif, juga terutama memberikan dampak negatif yang lebih besar. Di antara tujuan positif perceraian ketika halite menjadi jalan penyelamat satu-satunya bagi pasangan suami istri, antara lain:

\footnotetext{
${ }^{19}$ Mariani; Panitera Muda Hukum Pengadilan Agama Palopo, Wawancara.

20 Maswarni Bugis; Panitera Pengganti Pengadilan Agama Palopo, Wawancara, 17 Maret 2015.
} 
1. Pihak yang berperkara yang merasakan permasalahan keluarganya sebagai beban yang tidak dapat mencari jalan keluar lain akan menjadi lega, karena perpisahan tersebut tidak lagi menjadi beban pikiran, sehingga mereka dapat melakukan aktifitasnya kembali dengan berkurangnya satu beban pikiran.

2. Kemudian, dengan adanya Cerai Talak yang telah dilakasanakan maka kedua belah pihak (suami maupun isteri) lebih leluasa mencari pasangannya, dan hal itu dapat mencegah terjadinya perselingkuhan dan perzinaan terus-menerus. ${ }^{21}$

3. Ketika ada KDRT yang berlarut-larut yang dapat menimbulkan kemudaratan yang lebih besar dari yang sebelunya, akan lebih baik ketika isteri di ceraikan dari pada menjalani rumah tangga yang tidak sesuai dengan apa yang di dambakan oleh kedua belah pihak. ${ }^{22}$

Apabila dibandingkan antara dampak positif dari Cerai Talak dengan Dampak negatif yang ditimbulkannya, maka dampak negatifnya lebih besar. hal inilah salah satu hikmah yang dipahami ketika Allah swt dalam hadis mendudukkan masalah talak sebagai "Halal yang paling dibenci-Nya". dampak negatif yang ditimbulkannya antara lain:

1. Apabila Cerai Talak itu tidak dilakukan secara cermat maka anak yang diperoleh dari isteri yang terlantar terlantar.

2. Dengan perceraian itu hubungan antara mantan pasangannya bahkan sampai pada keluarga mantan pasangannya bisa berubah menjadi tidak baik.

3. Menjadi beban psikologis bagi anak, dan

4. Menjadi citra buruk di tengah-tengah masyarakat muslim pada umumnya.

\section{PENUTUP}

Kasus perceraian, khususnya dalam hal ini kasus cerai talak di Pengadilan Agama Kota Palopo mengalami peningkatan yang cukup sigifikan dari tahun ke tahun. Pada tahun 2011 terjadi 312 kasus perceraian, 109 kasus di antaranya adalah kasus cerai talak. Pada tahun 2012 terdapat 363 kasus perceraian, dan 117 kasus di antaranya adalah kasus cerai talak. Tahun 2013 tercatat 395 kasus perceraian, dan 140 kasus di antaranya adalah kasus cerai talak. tahun 2014 terdapat sedikitnya 511 kasus perceraian, dan 150 kasus di antaranya adalah kasus cerai talak. Hingga akhir Oktober 2015 (sesuai jadwal penelitian ini) telah tercatat 137 Kasus, dengan jumlah ratarata kasus cerai talak yang masuk dalam data Pengadilan Agama Kota Palopo, yaitu antara 12 sampai dengan 13 kasus setiap bulannya.

\footnotetext{
${ }^{21}$ Rahmani; Ketua Pengadilan Agama Palopo, Wawancara.

${ }^{22}$ Husnaena; Hakim Pengadilan Agama Palopo, Wawancara.
} 
Berbagai faktor penyebab terjadinya cerai talak di Kota Palopo, di antaranya di sebabkan karena krisis akhlak, masalah ekonomi, gangguan dari pihak ketiga, cemburu, dan lainnya yang mengakibatkan hilangnya keharmonisan dalam rumah tangga tersebut, sehingga pada akhirnya pihak suami menempuh jalan perceraian dengan mengajukan permohonan talak kepada Pengadilan agama Kota Palopo.

Adapun solusi cerai talak di Kota Palopo yaitu dengan cara melakukan mediasi secara terus-menerus baik sebelum persidangan maupun sesudah persidangan terhadap pihak yang berperkara. Adapun prosedur dari mediasi yaitu:

1. Memberikan penomoran perkara, kemudian ketua Pengadilan Agama menunjuk majelis hakim membuat penetapan untuk mediator supaya dilaksanakan mediasi.

2. Setelah pihak yang berperkara hadir dan majelis menyerahkan penetapan mediasi kepada mediator berikut pihak-pihak yang berperkara.

3. Selanjutnya mediator menyarankan kepada pihak-pihak yang berperkara supaya perkara ini diakhiri dengan jalan damai dengan berusaha mengurangi kerugian masing-masing pihak yang berperkara.

\section{DAFTAR PUSTAKA}

Abdul Rivai Rinom; Hakim Pengadilan Agama Kota Palopo. Wawancara, 3 Maret 2015.

Departemen Agama RI. Al-Quran dan Terjemahnya Al-Jumanatul 'Ali. Bandung: CV Penerbit J-Art, 2005.

Husnaena; Hakim Pengadilan Agama Palopo. Wawancara, 3 Juni 2015.

Mariani; Panitera Muda Hukum Pengadilan Agama Palopo. Wawancara, 24 Mei 2015.

Maswarni Bugis; Panitera Pengganti Pengadilan Agama Palopo. Wawancara, 17 Maret 2015.

Mustika bte Anwar; Pihak Berperkara di Pengadilan Agama Kota Palopo. Wawancara, 17 Maret 2015.

Rahmani; Ketua Pengadilan Agama Palopo. Wawancara, 23 Mei 2015.

Ramlan Mardjoned. Keluarga Sakinah (rumahku Syurgaku). 1 ed. Jakarta: Media Dakwah, 1999.

Slamet Abidin, dan Aminuddin. Fiqhi Munakahat I. 1 ed. Bandung: Pustaka Setia, 1999.

Umi Kalsum. Risalah Fiqih Wanita. 1 ed. Surabaya: Cahaya Mulya, 2007. 